\title{
HIV-1 gp120 Receptor on CD4-Negative Brain Cells Activates a Tyrosine Kinase
}

\author{
JÜRGEN SCHNEIDER-SCHAULIES, ${ }^{*, 1}$ SIBYLLE SCHNEIDER-SCHAULIES, * ROBERT BRINKMANN, * \\ PETRUS TAS, ${ }^{\star}$ MARIA HALBRÜGGE, + ULRICH WALTER, + HARVEY C. HOLMES, $\neq$ \\ AND VOLKER TER MEULEN*
}

\begin{abstract}
*Institut fur Virologie und Immunbiologie, Versbacher Str. 7, 8700 Würzburg, Germany; †Medizinische Universitatsklinik, Klinische Forschergruppe, Josef Schneider Str. 2, 8700 Würzburg, Germany; and ¥National Institute for Biological Standards and Control, AIDS Collaborating Centre, Blanche Lane, Potters Bar, Herts, U.K.
\end{abstract}

Received June 5, 1992; accepted August 19, 1992

\begin{abstract}
Human immunodeficiency virus (HIV-1) infection in the human brain leads to characteristic neuropathological changes, which may result indirectly from interactions of the envelope glycoprotein $\mathrm{gp} 120$ with neurons and/or glial cells. We therefore investigated the binding of recombinant gp120 (rgp120) to human neural cells and its effect on intracellular signalling. Here we present evidence that rgp 120, besides binding to galactocerebroside or galactosyl-sulfatide, specifically binds to a protein receptor of a relative molecular mass of approximately $180,000 \mathrm{Da}(180 \mathrm{kDa})$ present on the CD4-negative glioma cells D-54, but not on Molt4 T lymphocytes. Binding of rgp 120 to this receptor rapidly induced a tyrosine-specific protein kinase activity leading to tyrosine phosphorylation of 130 - and 115-kDa proteins. The concentration of intracellular calcium was not affected by rgp120 in these cells. Our data suggest a novel signal transducing HIV-1 gp120 receptor on CD4-negative glial cells, which may contribute to the neuropathological changes observed in HIV-1-infected brains. () 1992 Academic Press, Inc.
\end{abstract}

\section{INTRODUCTION}

Neuropathological changes in the central nervous system (CNS) of AIDS patients, which lead to the socalled AIDS dementia complex (ADC), are of great clinical importance. Manifestations of ADC are progressive cognitive, motor, and behavioral dysfunctions that have been linked to the persistence of HIV-1 infections in the CNS and are mainly found in CD4-positive $\left(\mathrm{CD}^{+}\right)$microglial cells and circulating macrophages (Budka, 1991; Fauci, 1988; Jordan et al., 1991; Ketzler et al., 1990; Liu et al., 1990; Maddon et al., 1986; McArthur, 1987; Merrill and Chen, 1991; Price et al., 1988). However, in the absence of CD4 molecules on the cell membrane of the majority of brain cells and in the light of the paucity of direct evidence for HIV infection of neurons and glial cells it has been suggested that the HIV-associated degenerative neurological abnormalities are the result of indirect mechanisms mediated by soluble factors of viral or cellular origin (Brenneman et al., 1988; Dreyer et al., 1990; Giulian et al., 1990; Kaiser et al., 1990; Pulliam et al., 1991; Wahl et al., 1991). These factors could be cytotoxic to subpopulations of brain cells or interfere with neuronal and glial cell functions leading to neurodegeneration.

One such factor, the HIV-1 envelope glycoprotein gp120, which is easily shed from infected cells, has been studied in the past. It was found that gp120 does

\footnotetext{
' To whom reprint requests should be addressed.
}

not only bind to the well-known CD4 molecules, but also to galactocerebroside (GalC) and galactosyl-sulfatide, cellular membrane components expressed on the surface of oligodendrocytes and other neural cells (Harouse et al., 1991; Kuhlmann-Krieg et al., 1988; Ranscht et al., 1982). Polyclonal antibodies to GalC can inhibit the entry of HIV-1 in neural cell lines, suggesting that the binding of HIV to these membrane structures might be of biological significance (Bhat et al., 1991; Harouse et al., 1991). However, to mediate signals possibly leading to cellular dysfunction, entry of viruses into cells is not necessary, but rather the interaction of HIV-1 or gp120 with cell surface receptors may be sufficient. Indeed, it was found that treatment of neuronal cultures of rodents with gp120 together with exitatory amino acids resulted in marked increases of intracellular calcium and ultimately in neuronal cell death (Brenneman et al., 1988; Choi, 1988; Dreyer et al., 1990; Kaiser et al., 1990; Lipton et al., 1991). These observations give certainly support to the hypothesis that soluble HIV-1 gp120 may interfere not only with neuronal, but also with glial cell functions and may be associated with the development of ADC.

To study the effect of HIV-1 gp120 on human brain cells, we used the human glioma cell line D-54, which does not express CD4 molecules. Investigation of these cells revealed high-affinity binding of rgp120 to a novel trypsin-sensitive receptor. Binding of gp 120 to these cells was leading to a tyrosine phosphorylation of 130 and $115 \mathrm{kDa}$ proteins in the absence of any 
increase of intracellular $\mathrm{Ca}^{2+}$. These data prove that binding of a HIV-1 structural protein alone to cell membrane molecules leads to signal transduction, which could be of pathogenetic significance.

\section{MATERIALS AND METHODS}

\section{Culture of cells}

The human malignant glioma cell lines $0-54$ and U-373 (Bigner et al., 1981) were cultured in Dulbecco's minimal essential medium (DMEM) containing streptomycin $(100 \mu \mathrm{g} / \mathrm{ml})$, penicillin $(100 \mathrm{U} / \mathrm{ml})$, and $5 \%$ fetal calf serum (FCS) at $37^{\circ}$ and $10 \% \mathrm{CO}_{2}$. The $\mathrm{CD}^{+} \mathrm{T}$ lymphocytic cells Molt4, $\mathrm{H} 9$ and $\mathrm{C} 8166$, and the CD4 ${ }^{-}$ $B$ lymphocytic cells BJAB were cultured in Roswell Park Memorial Institute (RPMI) 1640 medium containing the same additives.

\section{Polymerase chain reaction}

For PCR, $10^{5}$ cells were infected with HIV-1 (HTLVIIIB, a kind gift of R. Gallo; m.o.i. = 1). After 15 days (three passages), DNA was prepared and virus-specific DNA amplified with the gag-specific primers SK38 and SK39 and Taq-polymerase (Boehringer-Mannheim) as described (Ou et al., 1988). DNA was separated on a $15 \%$ polyacrylamide gel and blotted on nitrocellulose. After hybridization with the end-labeled 41-bp fragment SK19 of HIV-1, filters were exposed to $X$-ray films (DuPont).

\section{Preparation of RNA and Northern blot}

Total cellular RNA was prepared as described (Chirgwin et al., 1979). Poly-A+-RNA was selected on oligo-dT-cellulose (Sigma). Eight micrograms of poly$\mathrm{A}^{+}$-RNA per lane was separated on $1.5 \%$ agarose gels containing $6.3 \%$ formaldehyde and blotted on Hybond $\mathrm{N}$ filters (Amersham) by diffusion. As hybridization probes the 0.6-kb EcoRI/Sacl fragment of CD4-cDNA of plasmid T4-pMV6tk/neo (a gift of Dr. D. R. Littman, Columbia University, New York) and the 1.3-kb Pstl fragment of a plasmid containing the rat glyceraldehyde-3-phosphate-dehydrogenase (GAPDH) cDNA were labeled with [ $\left.{ }^{32} \mathrm{P}\right] \mathrm{dCTP}$ with a random-primed labeling kit (Boehringer-Mannheim).

\section{Immunofluorescent staining and flow cytometry}

To quantify surface molecule expression by flow cytometry, cells were harvested with $\mathrm{Ca}^{2+}$ - and $\mathrm{Mg}^{2+}$-free PBS. To partially remove surface proteins, $2 \times 10^{5}$ cells/tube were incubated with $1 \mathrm{ml} 0.1 \%$ trypsin in PBS for $10 \mathrm{~min}$ at room temperature, centrifuged, the supernatant aspirated, and washed once with $1 \mathrm{ml} \mathrm{me-}$ dium containing 10\% FCS and two times with $1 \mathrm{ml}$
$\mathrm{Ca}^{2+}$ and $\mathrm{Mg}^{2+}$-free PBS containing 0.2\% BSA (FACS-buffer). For rgp120-binding studies, cells were incubated with $200 \mu \mathrm{l} 1 \mu \mathrm{g} / \mathrm{ml}$ rgp 120 (strain IIIB; MRC Directed AIDS Programme) for $1 \mathrm{hr}$ on ice, washed three times with FACS-buffer and stained with antigp120 and FITC-conjugated second antibodies. The following monoclonal antibodies (mAbs) were used: mouse IgG, (Dako) as negative control; anti-CD4 mAb OKT4 (Ortho Diagnostics); anti-MHC class I mAb W6/ 32; anti-GalC mAb (Boehringer-Mannheim); anti-galactosyl-sulfatide mAb O4 (a gift of M. Schachner, ETHZürich, Switzerland); anti-gp120 mAb (DuPont); FITCconjugated rabbit anti-mouse Ig mAb (Dako).

\section{Labeling of rgp120 with ${ }^{125}$ and binding studies}

Labeling of rgp120 (strain IIIB; MRC Directed AIDS Programme) was performed by lactoperoxidase with single-reaction enzymobead radioiodination reagent (Bio-Rad). rgp120 (5 $\mu \mathrm{g})$ in $75 \mu / 0.2 M$ phosphate buffer, pH 7.2, $25 \mu$ l containing $1.0 \mathrm{mCi} \mathrm{Na}^{125}$ (Amersham) and $25 \mu \mathrm{l}$ containing $1 \%$ beta-D-glucose, were added to $50 \mu$ l rehydrated enzymobead reagent. The reaction mixture was incubated for $25 \mathrm{~min}$ at room temperature, directly applied to a gel filtration column (Sephadex-G25), and eluted with PBS into ice-cold tubes. Binding studies were performed with fractions containing rgp120 labeled to a specific activity of approximately $1200 \mathrm{cpm} / \mathrm{pmol}$ in $5 \mathrm{ml}$ PBS containing $0.5 \% \mathrm{BSA}$ for $2 \mathrm{hr}$ at $4^{\circ}$. Cells were washed three times quickly with ice cold PBS $0.5 \%$ BSA and cell-bound radioactivity and supernatants counted in a gammacounter (LKB).

\section{Chemical crosslinks}

For crosslinking $5 \times 10^{6}$ cells were harvested with $\mathrm{Ca}^{2+}$ - and $\mathrm{Mg}^{2+}$-free PBS and incubated for $2 \mathrm{hr}$ on ice with $0.1 \mu \mathrm{g}\left[{ }^{125} \mid\right] \mathrm{rgp} 120$ in $100 \mu \mathrm{l}$. After washing four times with PBS, cells were resuspended in $100 \mu$ PBS. The crosslinkers disuccinimidyl-suberate (DSS, stock: $50 \mathrm{mM}$ in DMSO, Pierce) and bis-(sulfosuccinimidyl)suberate (BS ${ }^{3}$, stock: $50 \mathrm{mM}$ in PBS, Pierce) were added to final concentrations of $0.2 \mathrm{mM}, 1 \mathrm{mM}$, and 5 $\mathrm{mM}$, and the suspensions incubated $1 \mathrm{hr}$ at room temperature. Cells were lysed by addition of 1 volume lysis buffer $(1 \%$ Triton X-100, $1 \%$ Na-deoxycholate, $0.1 \%$ SDS, $150 \mathrm{mM} \mathrm{NaCl}, 10 \mathrm{mM}$ Tris- $\mathrm{HCl}, \mathrm{pH} 7.4,0.1 \mathrm{mM}$ PMSF), and centrifuged for $10 \mathrm{~min}$ at $10,000 \mathrm{~g}$. Supernatants were separated by polyacrylamide gel electrophoresis with $6 \%$ sodium dodecylsulfate (SDS-PAGE) and dried gels exposed to $X$-ray films (DuPont) for 7 days. 


\section{Fura-2 loading and $\mathrm{Ca}^{2+}$ measurements}

For determination of intracellular $\mathrm{Ca}^{2+} 10^{7} \mathrm{D}-54$ cells were harvested, washed with buffer $\mathrm{A}(150 \mathrm{mM} \mathrm{NaCl}$, $5 \mathrm{mM} \mathrm{KCl}, 2 \mathrm{mM} \mathrm{CaCl}, 0.4 \mathrm{mM} \mathrm{MgSO}_{4}, 25 \mathrm{mM}$ glucose, and $25 \mathrm{mM}$ HEPES, $\mathrm{pH} 7.3$ ), and resuspended in buffer A. Fura-2 AM (1 $\mathrm{mM}$ in dimethylsulfoxide) was added to a final concentration of $5 \mu \mathrm{M}$. After incubation for $1 \mathrm{hr}$ at $36^{\circ}$, the cells were washed twice and resuspended in buffer $A$. Assays were carried out at $32^{\circ}$ with a modified 4-8202 Aminco-Bowman spectrofluorimeter (Silver Spring, MD) fitted with a magnetic stirrer and a thermostated cuvette holder. Intracellular fura-2 fluorescence intensity was measured at two excitation wavelengths ( 340 and $385 \mathrm{~nm}$ ) and continuously recorded at $500 \mathrm{~nm}$. Cells were treated with $0.01-1.0$ $\mu \mathrm{g} / \mathrm{ml} \mathrm{rgp} 120$ and for control with $10 \mathrm{U} / \mathrm{ml}$ thrombin (Sigma). At the end of each individual trace, cells were permeabilized with $0.1 \%$ Triton $X-100$ to yield the fluorescence signals of high $\mathrm{Ca}^{2+}$. Then $8 \mathrm{mM}$ EGTAV50 $\mathrm{mM}$ Tris was added to give the fluorescence signals for minimal $\mathrm{Ca}^{2+}$ concentration ( $<1 \mathrm{~nm}$ ). $\mathrm{Ca}^{2+}$ values were calculated according to the equation given in Grynkiewicz et al. (1985) using the $340 / 385 \mathrm{~nm}$ ratio of fluorescence intensities and the $\mathrm{Ca}^{2+}$-dye dissociation constant $\left(K_{\mathrm{d}}=224 \mathrm{nM}\right)$.

\section{Detection of phosphotyrosine by Western blot}

To determine tyrosine phosphorylation, $5 \times 10^{5}$ cells were incubated with rgp 120 in $1 \mathrm{ml}$ complete culture medium, aspirated and dissolved in $300 \mu$ lysis buffer (200 $\mu$ l PBS plus $100 \mu l 200 \mathrm{mM}$ Tris $-\mathrm{HCl}, \mathrm{pH} 6.8,5 \%$ SDS, $15 \%$ glycerol, $10 \% \beta$-mercapto ethanol, $0.01 \%$ bromophenol blue), and applied to $8 \%$ SDS-PAGE (100 $\mu \mathrm{g} /$ lane). A semidry Western blot on nitrocellulose filters (Schleicher \& Schüll) was performed as described (Kyhse-Andersen, 1984) and the background blocked with $1 \%$ BSA and $1 \%$ gelatine in TNA $(10 \mathrm{mM}$ Tris- $\mathrm{HCl}, \mathrm{pH} 7.2,150 \mathrm{mM} \mathrm{NaCl}, 0.01 \% \mathrm{NaN}_{3}$ ) overnight. Anti-phosphotyrosine monolonal antibody PY20 (ICN Flow) diluted 1:1000 in blocking buffer was applied for $2 \mathrm{hr}$. After washing for $3 \times 5 \mathrm{~min}$ with TNA and 5 min with TNA containing $0.05 \%$ NP-40, filters were incubated with ${ }^{125}$-labeled anti-mouse IgG (Amersham) diluted 1:350 in blocking buffer for $2 \mathrm{hr}$. Filters were washed $6 \times 10$ min with TNA and overnight with TNA containing $0.05 \%$ NP-40 and exposed to $X$-ray films (DuPont). Sodium orthovanadate $(20 \mu \mathrm{M})$ was present in all solutions.

\section{RESULTS}

\section{The human glioma cell line D-54 is CD4-negative}

For our studies on rgp120-cell interactions we selected D-54 glioma cells, because these cells are
A

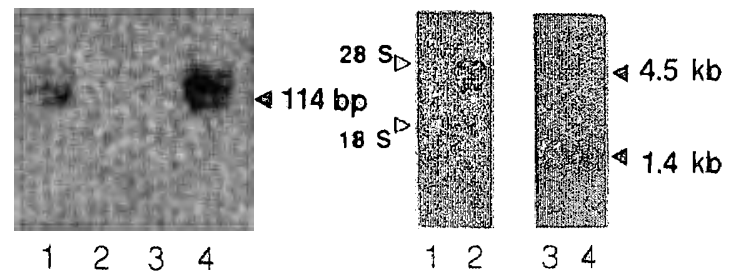

FIG. 1. Uptake of HIV-1 by D-54 cells (PCR analysis) and lack of CD4-specific mRNA in D-54 cells (Northern blot). (A) The uptake of low amounts of HIV-1 by D-54 cells was measured by polymerase chain reaction (PCR). DNA from D-54 cells was amplified with the HIV-1 gag-specific primers SK38 and SK39, the amplification products blotted on nitrocellulose and hybridized to a radioactively labeled gag-specific probe. The 114 bp HIV-1 gag-specific DNA fragment was detected in D-54 cells 15 days after infection with HIV-1 (lane 1), but not in uninfected D-54 cells (lane 2) and in buffer without DNA (lane 3). The HIV-1-infected CD4 ${ }^{+}$lymphocytes $\mathrm{H} 9$ were used as positive control (lane 4). Since cellular DNA was amplified, uptake and reverse transcription of viral RNA occured in D54 cells. (B) Poly $\mathrm{A}^{+}$-RNA from cell lines was blotted on Hybond $\mathrm{N}$ filters and hybrid ized to a CD4-specific radioactively labeled probe. CD4-specific mRNA was not detected in D-54 cells (lane 1). In contrast, the CD4 ${ }^{+}$ lymphocytes C8166 expressed CD4 mRNA at $4.5 \mathrm{~kb}$ (lane 2). The amount of intact RNA on the filter was controled by hybridization with a GAPDH-specific probe revealing similar signals for RNA from D-54 (lane 3) and C8166 cells (lane 4). The position of $28 \mathrm{~S}$ and $18 \mathrm{~S}$ RNA is indicated as size marker.

highly responsive to external stimuli like cAMP-analogs (Bigner et al., 1981) and might therefore be good candidates to investigate signal transduction. We first assessed these cells for susceptibility to HIV-1 and presence of CD4 molecules. Like the neuronal cell lines SK-N-BE and IMR-32 and the glioblastoma line U-373 (Li et al., 1990; Harouse et al., 1989), we found that the glioblastoma line D-54 was nonproductively infected with HIV-1. In the absence of production of infectious virus and the development of a cytopathogenic effect (CPE), HIV-1-specific DNA could be detected in D-54 cells by polymerase chain reaction (Fig. $1 \mathrm{~A}$ ) as well as p24 core antigen, although these cells did not contain CD4-specific mRNA or truncated RNAs (Fig. 1B). In addition, we confirmed by immunofluorescent staining and flow cytometry that these cells, in contrast to the $T$ cell line Molt4, did not express CD4 on their surfaces (Fig. 2A, 2B). Obviously, binding and entry of HIV-1 into D-54 cells occured by a CD4-independent mechanism.

\section{D-54 glioma cells express galactosyl-sulfatide}

GalC and galactosyl-sulfatide have been found to bind HIV-1 gp120 as purified substances and on the surface of neural cells (Bhat et al., 1991; Harouse et al., 1991). Therefore, we determined the expression of 
A

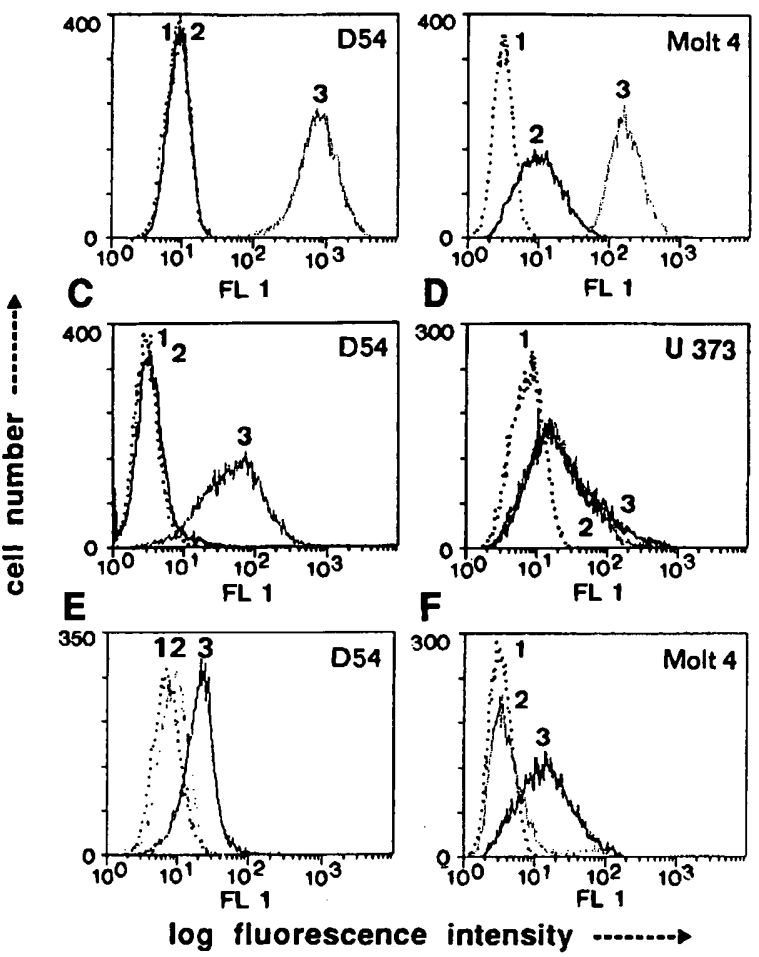

Fig. 2. Expression of surface molecules and binding of rgp 120 to CD4-negative human glioma cells determined by flow cytometry. (A) CD4 was not detectable on the surface of D- 54 cells: negative control (signal 1), CD4 (signal 2), major histocompatibility complex (MHC) class I as positive control (signal 3). (B) As control, CD4 was detectable on Molt4 cells: negative control (signal 1), CD4 (signal 2), MHC class I (signal 3). (C) D-54 cells did not express GalC, but galactosyl-sulfatide: negative control (signal 1), GalC (signal 2), and galactosyl-sulfatide (signal 3). (D) U-373 cells expressed GalC and galactosyl-sulfatide: negative control (signal 1), galactosyl-sulfatide (signal 2), and GalC (signal 3). (E) Detection of rgp 120 bound to D-54 cells by anti-gp 120 antibodies: negative control (signal 1), rgp 120 on trypsin-treated D-54 (signal 2), and rgp 120 bound to D-54 cells (signal 3). (F) $\mathrm{CD}^{+}$Molt4 cells did bind rgp 120: negative control (signal 1). rgp 120 on trypsin treated Molt4 (signal 2), rgp 120 bound to Molt4 cells (signal 3).

GalC and galactosyl-sulfatide on D-54 cells by immunofluorescent staining with monoclonal antibodies and flow cytometry. D-54 cells were not stained with antibodies to GalC, but expressed galactosyl-sulfatide on their surfaces (Fig. 2C). As control we stained U-373 cells, which expressed GalC and galactosyl-sulfatide (Fig. 2D). We now investigated whether galactosyl-sulfatide is the only molecule on D-54 cells capable of binding gp120, or if a further class of binding sites might be expressed on these cells.

\section{Binding of rgp120 to cell surfaces}

To roughly estimate the amount of purified $\mathrm{CHO}$ cellderived recombinant gp120 of HIV-1 (strain IIIB) capa- ble of binding to D-54 cells, we first used immunofluorescent staining methods and analysis by flow cytometry. After stringent washing, low, but significant levels of rgp120 binding to D-54 cells remained detectable, when compared to CD4 ${ }^{+}$Molt4 cells (Fig. 2E, 2F). In addition, we made the interesting observation that the specific binding of rgp120 was decreased after treatment of both cell lines with trypsin (Fig. 2E, 2F). Since galactosyl-sulfatide is not sensitive to trypsin, these results suggested the presence of a proteinous receptor for gp120 on the surface of D-54 cells.

To determine the exact binding properties of rgp120 to D-54 cells, rgp120 was labeled with ${ }^{125}$ lodine (Fig. $3 A)$. The affinity constant for the rgp120-D-54 cell interaction was assessed by whole cell binding assays. Providing ${ }^{125}$-labeled rgp120 up to a concentration of $100 \mathrm{nM}$, we could not reach the level of saturation (Fig. $3 \mathrm{~B})$, but the binding of ${ }^{125} \mathrm{~F}$-labeled rgp120 (400 $\mathrm{f} / \mathrm{M} / 10^{6}$ cells) was specifically inhibited by $50 \%$ with approximately $20 \mathrm{nM}$ unlabeled rgp120 (not shown). Intermediate saturation of high-affinity binding sites of rgp 120 on D-54 cells was detected already at a free concentration of 300 to $500 \mathrm{f} M \mathrm{rgp} 120$, whereas at higher concentrations low-affinity binding increased. Scatchard analysis of these data revealed binding sites with a dissociation constant $\left(K_{d}\right)$ of approximately $1.2 \times$ $10^{-10} \mathrm{M}$ for high-affinity and $3.2 \times 10^{-9} \mathrm{M}$ for low-affinity binding sites (Fig. 3C). The abundance of receptor sites on D-54 cells was determined to be approximately $7 \times 10^{4} /$ cell for high affinity receptors and more than $10^{6} /$ cell for lower affinity receptors (average of eight experiments). The flow cytometry data suggest that at least one of these receptors is trypsin sensitive and therefore of proteinous nature, whereas the other is likely to be galactosyl-sulfatide.

\section{Crosslinking of rgp120 to cell surface molecules}

To investigate the nature of the trypsin-sensitive gp120 receptors on D-54 cells, we performed crosslinking experiments with several chemical crosslinkers. Using the crosslinkers disuccinimidyl suberate (DSS) and bis(sulfosuccinimidyl) suberate $\left(\mathrm{BS}^{3}\right)$, we detected one labeled ligand-receptor complex at approximately 300 kDa with D-54 cells, but not with Molt4 cells (Fig. 4). The intensity of this $300-\mathrm{kDa}$ band (Fig. 4, lanes 3-8) was relatively low, as compared to cross-linked CD4 molecules on the surface of Molt4 cells (Fig. 4 , lanes 9-11). Increasing concentrations of cross-linkers led to high molecular weight complexes with D-54 and Molt4 surface molecules on top of the gel (Fig. 4, lanes $5,8,11)$. The $300-k D a$ complex is unlikely to consist of cross-linked rgp120 molecules itselves, since we did not observe bands of dimerized gp 120 with a molecu- 
A

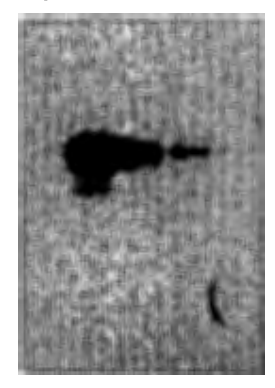

$123 \quad 4 \quad 5$
B

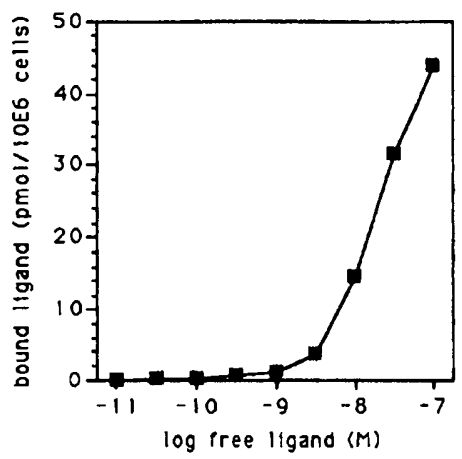

C

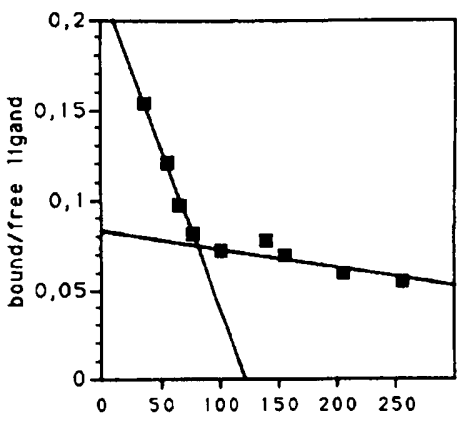

bound ligand (Imol/5ml/10E6 cells)

FIG. 3. Labeling of rgp 120 and analysis of binding to D-54 cells. (A) Purified ${ }^{125}$-labeled rgp 120 visualized after separation on $10 \%$ SDS-PAGE by autoradiography. Fractions 2 and 3 from the gel filtration column (lanes 2 and 3) were used for binding studies. (B) To measure binding of rgp 120 to D-54 cells, $1 \times 10^{8}$ cells in several experiments were incubated with $20 f M$ to $100 \mathrm{nM}{ }^{125}$-labeled rgp 120. The logarithmic binding curve of one representative experiment with $1 \times 10^{8} \mathrm{D}-54$ cells is shown. (C) Scatchard analysis of low concentrations of rgp 120 binding to D-54 cells. Binding sites with equilibrium dissociation constants $\left(K_{\mathrm{d}}\right)$ of approximately $1.2 \times 10^{-10} \mathrm{M}$ and $3.2 \times 10^{-8} \mathrm{M}$ were found for high-and low-affinity classes of receptors. High-affinity binding corresponded to approximately $7 \times 10^{4}$ binding sites/cell and low-affinity binding to more than $10^{6}$ binding sites/cell.

lar weight of $240 \mathrm{kDa}$ and trimerized gp 120 with a molecular weight of $360 \mathrm{kDa}$ and also no bands between 120 and $240 \mathrm{kDa}$ with D-54 cells. Furthermore, the 300-kDa complex could not be observed when D-54 cells were harvested with trypsin or treated with trypsin after harvesting (not shown). In contrast, cross-linking on Molt4 cells, which were capable of crosslinking much more ${ }^{125}$-labeled rgp120 than D-54 cells, revealed in addition to the $180 \mathrm{kDa}$ band also a weak

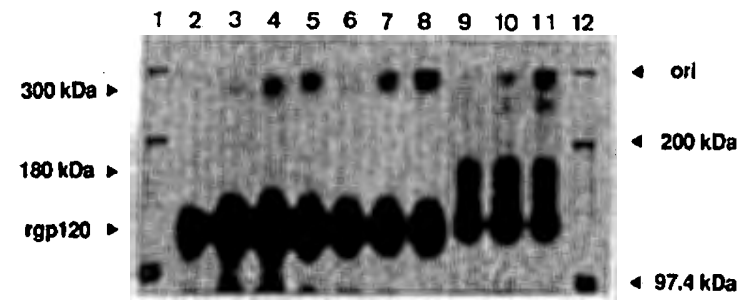

FIG. 4. Cross-linking of rgp 120 to cell surface proteins of D-54 and Molt4 cells. ${ }^{14} \mathrm{C}$-labeled marker proteins had molecular masses of $200 \mathrm{kDa}$ and $97.4 \mathrm{kDa}$ (lanes 1 and 12). ${ }^{125}$-labeled rgp120 was incubated with D-54 cells (lanes 2-8) and with Molt4 cells (lanes $9-11$ ). Incubation of D-54 with ${ }^{125}$-labeled rgp 120 in the absence of crosslinker (lane 2) did not lead to higher molecular weight complexes. Increasing concentrations $(0.2 \mathrm{mM}, 1 \mathrm{mM}, 5 \mathrm{mM})$ of the cross-linkers disuccinimidyl suberate (DSS) (lanes 3-5 and 9-11) and bis(sulfosuccinimidyl) substrate $\left(\mathrm{BS}^{3}\right.$ ) (lanes $6-8$ ) led to one ligand-receptor complex with an approximate relative molecular mass of $300 \mathrm{kDa}$ (lanes $3-8$ ). The crosslink of the CD4 molecule (60 $\mathrm{kDa}$ ) on Molt 4 cells with rgp 120 was used as positive control giving a complex of $180 \mathrm{kDa}$ (lanes 9-11). A diffuse band of approximately $240 \mathrm{kDa}$ was also seen with Molt4 cells, which is likely to consist of the dimerization product of rgp 120. Unspecific high molecular weight complexes at the top of the gel accumulated with increasing concentrations of crosslinkers (lanes $5,8,11$ ). band at $240 \mathrm{kD}$, probably the dimerization product of rgp120. Therefore, the $300-k D a$ complex observed with D-54 cells is likely to consist of ${ }^{125}$-labeled rgp 120 cross-linked to a single $180-k D a$ molecule. Taken together, these data indicate that a trypsin-sensitive $180-k D a$ cell surface protein might be a high-affinity receptor for gp 120 .

\section{Determination of intracellular calcium concentrations}

Recent reports on the neurotoxicity of gp120 in cell culture suggested that signal transduction through an unknown surface molecule may disturb cellular functions by raising intracellular $\mathrm{Ca}^{2+}$ concentrations (Brenneman et al., 1988; Dreyer et al., 1990; Kaiser et al., 1990; Pulliam et al., 1991). When we measured intracellular $\mathrm{Ca}^{2+}$ concentrations in D-54 cells in response

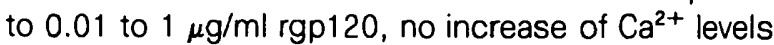
could be detected (Fig. 5A). As control, we measured a high response of $\mathrm{Ca}^{2+}$ increase after treatment of cells with $10 \mathrm{U} / \mathrm{ml}$ thrombin (Fig. 5B), ionomycin and Triton $\mathrm{X}-100$ (not shown). Thus, intracellular $\mathrm{Ca}^{2+}$ concentrations were not affected by rgp 120 in D-54 cells.

\section{Activation of tyrosine phosphorylation by rgp 120}

Assessing a different signal transduction pathway, namely the activation of cellular tyrosine kinases, we observed a rapid induction of tyrosine phosphorylation of proteins after interaction of rgp 120 with D-54 cells (Fig. 6). The phosphotyrosine-specific antibody used in this Western blot detected a predominant molecular species at $130 \mathrm{kDa}$ and a minor band at $115 \mathrm{kDa}$ after 

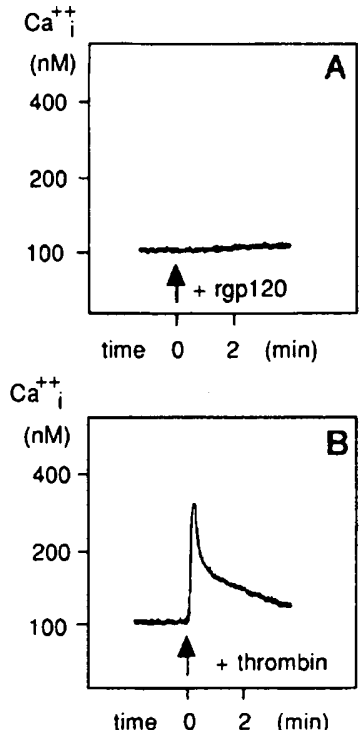

Fig. 5. Intracellular calcium concentration in human glioma cells. D-54 cells loaded with fura-2 were treated with $1 \mu \mathrm{g} / \mathrm{ml} \mathrm{rgp} 120(\mathrm{~A})$ and $10 \mathrm{U} / \mathrm{ml}$ thrombin (B) as a positive control. The intracellular fluorescence intensity was measured at two excitation wavelengths ( 340 and $385 \mathrm{~nm}$ ) and continuously recorded at $500 \mathrm{~nm}$ with a spectrofluorimeter. The computed intracellular $\mathrm{Ca}^{2+}$ concentration (vertical axis) was plotted as a function of time (horizontal axis). No response to rgp 120 could be detected.

$0.5,1.0$, and $10 \mathrm{~min}$ of incubation of cells with $1 \mu \mathrm{g} / \mathrm{ml}$ rgp120 (Fig. 6, lanes 4-6). Maximal tyrosine phosphorylation was found already 0.5 to 1.0 minutes after treatment of D-54 cells with rgp 120. In contrast, the lymphocytic cells Molt4 (Fig. 6, lanes 7-10) and BJAB (not shown) did not reveal tyrosine phosphorylation in response to rgp120. Tyrosine phosphorylation was also not observed after treatment of D-54 cells with antibodies to galactosyl sulfatide (not shown). Induction of tyrosine phosphorylation was completely abolished by pretreatment of the cells with trypsin (Fig. 6 , lanes 11, 12), indicating that trypsin-sensitive cell surface proteins are essential for transmission of the signal.

\section{DISCUSSION}

Our results indicate that a surface molecule of approximately $180 \mathrm{kDa}$ expressed on the surface of the human glioma cells D-54 might be a novel receptor for gp120, which transduces either itself, or as a receptor complex, a signal leading to tyrosine phosphorylation of two proteins with molecular masses of 130 and 115 $\mathrm{kDa}$. The human glioma cells did not express the main HIV-1 receptor CD4 as mRNA or as protein on their surfaces. It has been described that several CD4- cells are susceptible to HIV-1, implicating the existence of additional HIV-1 receptors on neural cells (Clapham et al., 1989; Harouse et al., 1989, 1991; Kozlowski et al., 1991; Li et al., 1990; Mizrachi et al., 1991; Schmitt et al., 1990). The only known molecular species expressed on the surface of D-54 cells capable of binding gp120 was found to be galactosyl-sulfatide. A similar molecule, GalC, has been described to bind rgp120 with an affinity of $1.16 \times 10^{-10} \mathrm{M}$ (Harouse et al., 1991), which is higher than the affinity of rgp 120 binding to

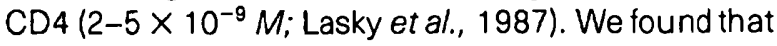
D-54 cells express two classes of binding sites with higher $\left(1.2 \times 10^{-10} \mathrm{M}\right)$ and lower $\left(3.2 \times 10^{-9} \mathrm{M}\right)$ affinity to rgp 120. When compared with the results of Harouse et al. (1991), our affinity data suggest that the higher affinity receptors consist of galactosyl-sulfatide and the lower affinity receptors of the trypsin-sensitive cell surface proteins. We also determined the binding of rgp 120 to trypsin-treated D-54 cells. But the resulting values of the binding assays were partially higher than of untreated cells and could not be evaluated properly. A possible explanation for these results could be that galactosyl-sulfatide epitopes are unmasked by the treatment with trypsin and led to higher binding values.

By chemical cross-linking of ${ }^{125}$-labeled rgp 120 to cell surface molecules we detected one ligand-receptor complex of approximately $300 \mathrm{kDa}$. The crosslinkers DSS and $\mathrm{BS}^{3}$ do not link lipids like galactosylsulfatide to proteins, since reactive amino groups are missing. Therefore, the 300-kDa complex cross-linked by DSS and $\mathrm{BS}^{3}$ is likely to consist of rgp 120 and the trypsin-sensitive cell surface component binding rgp120. Since no smaller complexes of dimerization

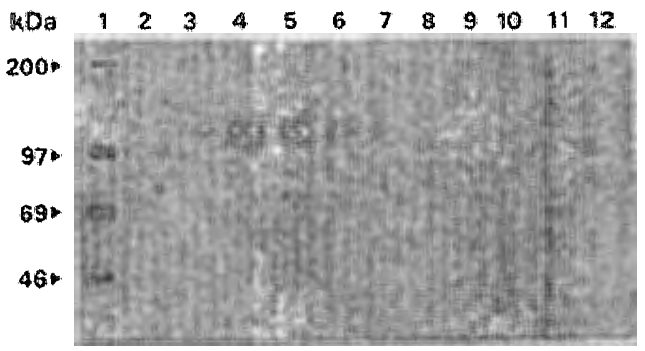

Fig. 6. Tyrosine phosphorylation induced by rgp120-treated human glioma cells. ${ }^{14} \mathrm{C}$-labeled marker proteins had the molecular masses of $200,97,69$, and $46 \mathrm{kDa}$ (lane 1). The following lanes were loaded with the extracts of $D .54$ and Molt4 cells in culture medium, respectively (lanes 2 and 7); D-54 cells incubated with anti-gp 120 antibody (lane 3); D-54 and Molt4 cells incubated with $1 \mu \mathrm{g} / \mathrm{ml}$ rgp 120 for $0.5,1$, and $10 \mathrm{~min}$, respectively (lanes $4-6$ and 8-11); D-54 cells preincubated with $0.1 \%$ trypsin for $10 \mathrm{~min}$, washed, and then incubated with $1 \mu \mathrm{g} / \mathrm{ml}$ rgp 120 for 0.5 and $1 \mathrm{~min}$ (lanes 11 and 12). Induced tyrosine phosphorylation of 130 and $115 \mathrm{kDa}$ proteins was detected only in the glioblastoma line D-54. 
products or complexes of degradation products of rgp 120 were detected with D-54 cells, it is likely that a single molecular species of approximately $180 \mathrm{kDa}$ was cross-linked to rgp 120. The low intensity of the cross-linked complex in comparison to the CD4rgp120 complex on Molt4 cells is astonishing, since the number of CD4 molecules per cell is similar to the number of high-affinity receptors and less than the number of lower affinity receptors on D-54 cells. Because of the low intensity, one could suppose that the protein receptor corresponds to the lower abundance, higher affinity class of binding sites. However, one reason for the low intensity of the cross-linked complex could be that cross-linking of rgp 120 with the protein receptor with lower affinity to gp120 is competed by the higher affinity binding of rgp 120 to galactosyl-sulfatide on the surface of D-54 cells.

It was found that antibodies to the membrane lipid GalC can induce an increase of intracellular $\mathrm{Ca}^{2+}$ concentrations in oligodendrocytes, but only after treatment of cells with very high concentrations of antibodies $(\geqslant 470 \mu \mathrm{g} / \mathrm{ml}$; Dyer and Benjamins, 1990). We did not detect any increase of intracellular $\mathrm{Ca}^{2+}$ in response to rgp120 in D-54 cells. The signal transduction pathway of the observed tyrosine phosphorylation is clearly of a different nature, since antibodies to galactosyl-sulfatide did not lead to tyrosine phosphorylation, and treatment of cell surfaces with trypsin abolished the transduced phosphorylation signal. The tyrosine-phosphorylated 130-and 115-kDa proteins might be subunits of a receptor complex with the crosslinked 180-kDa rgp120-binding molecule. However, it is not possible to clearly judge whether phosphorylation is inter- or intramolecular based on the rapid kinetic of tyrosine phosphorylation in intact cells. Our control using $\mathrm{CD}^{+}$Molt4 cells did not reveal induction of tyrosine phosphorylation in response to rgp120, which is in accordance with the results of Horak et al. (1990) for T lymphocytes. Tyrosine phosphorylation of proteins with molecular masses in the range of 110 to $140 \mathrm{kDa}$ has been described to occur after activation of many cell surface receptors on brain cells including receptors for neurotrophic factors (Soppet et al., 1991; Squinto et al., 1991), the interleukin-6 receptor (Hibi et al., 1990), and receptors of the integrin family (Kornberg et al., 1991). It will be of great interest to identify the nature of the receptor complex we found and the tyrosine kinase involved.

Programmed cell death or apoptosis is a physiological mechanism involved in normal tissue turnover during embryogenesis and adult life, especially in the brain, bone marrow and thymus (McConkey et al., 1990). In AIDS patients, this mechanism has been suggested to be responsible for $T$ helper cell depletion
(Ameisen and Caprone, 1991) and could also cause cellular dysfunction and atrophy as observed in the brain (Fauci, 1988). In addition, the HIV envelope glycoprotein gp120 has been shown to increase intracelIular $\mathrm{Ca}^{2+}$ concentrations together with NMDA receptor agonists and to injure rodent neurons in vitro (Brenneman et al., 1988; Dreyer et al., 1990; Lipton et al., 1991). These mechanisms and the observed tyrosine phosphorylation in response to rgp120 in glial cells could provide a combination of signals leading to astrocytosis, impairment of myelin, and neurodegeneration as found in brains of AIDS patients. Further experiments are required to investigate the pathogenetic significance of this tyrosine kinase signal transduction pathway in neuro-AIDS.

\section{ACKNOWLEDGMENTS}

We thank M. Bayer and K. Pech for excellent technical assistance, Dr. D. D. Bigner, Durham, for providing us with the neural cell lines, Dr. E. Schomig. Wurzburg, Germany, and Dr. P. Presek, Giessen, Germany, for helpful discussions, and the MRC Directed AIDS Programme for supplying the rgp 120. This work was supported by Deutsche Forschungsgemeinschaft and Bundesministerium fur Forschung und Technologie.

\section{REFERENCES}

AMEISEN, J. C., and CAPRON, A. (1991). Cell dysfunction and depletion in AIDS: The programmed cell death hypothesis. Immunol. Today 12, 102-105.

Bhat, S., Spitalnid, S. L., Gonzales-Scarano, F., and Silberberg, D. H. (1991). Galactosyl ceramid or a derivative is an essential component of the neural receptor for human immunodeficiency virus type 1 envelope glycoprotein gp 120. Proc. Natl. Acad. Sci. USA 88, 7131-7134.

Bigner, D. D., Bigner, S. H., Pontén, J., Westermark, B., Mahaley, M. S., Ruoslahti, E., Herschman, H., ENG, L. F., and Wikstrand, C. J. (1981). Heterogeneity of genotypic and phenotypic characteristics of fifteen permanent cell lines derived from human gliomas. J. Neuropathol. Exp. Neurol. 15, 201-229.

Brenneman, D. E., Westbrook, G. L., Fitzgerald, S. P., Ennist, D. L., Elkins, K. L., RUFF, M. R., and PERT, C. B. (1988). Neuronal cell killing by the envelope protein of HIV and its prevention by vasoactive peptide. Nature 335, 639-642.

BUDKA, H. (1991). Neuropathology of human immunodeficiency virus infection. Brain Pathol. 1, 163-175.

Chirgwin, J. M., Przybyla, A. E., MacDonalo, R. J., and RUTter, W. J. (1979). Isolation of biologically active ribonucleic acids from sources enriched in ribonuclease. Biochemistry 18, 5294-5299.

CHOI, D. W. (1988). Glutamate neurotoxicity and diseases of the nervous system. Neuron 1, 623-634.

Clapham, P. R., Weber, J. N., Whitby, D., Mcintosh, K., Dalgleish, A. G., Maddon, P. J., DeEn, K. C., Sweet, R. W., and Weiss, R. A. (1989). Soluble CD4 blocks the infectivity of diverse strains of HIV and SIV for $T$ cells and monocytes but not for brain and muscle cells. Nature 337, 368-370.

Dreyer, E. B., Kaiser, P. K., OffFermann, J. T., and Lipton, S. A. (1990). HIV-1 coat protein neurotoxicity prevented by calcium channel antagonists. Science 248, 364-367.

DYER, C. A., and BENJAmins, J. A. (1990). Glycolipids and transmem- 
brane signalling: Antibodies to galactocerebroside cause influx of calcium in oligodendrocytes. J. Cell Biol. 111, 625-633.

FAUCl, A. S. (1988). The human immunodeficiency virus: Infectivity and mechanisms of pathogenesis. Science 239, 617-622.

GIULIAN, D., VACA, K., and NoONAN, C. A. (1990). Secretion of neurotoxins by mononuclear phagocytes infected with HIV-1. Science 250, 1593-1596.

Grynkiewicz, G., Poenie, M., and TSIEN, R. Y. (1985). A new generation of $\mathrm{Ca}^{++}$indicators with greatly improved fluorescence properties. J. Biol. Chem. 260, 3440-3450.

harouse, J. M., Bhat, S., Spitalnik, S. L., Laughlin, M., Stefano, K., SilberberG, D. H., and Gonzales-Scarano, F. (1991). Inhibition of entry of HIV-1 in neural cell lines by antibodies against galactosyl ceramide. Science 253, 320-323.

harouse, J. M., Kunsch, C., Hartle. H. T., Laughlin, M. A., Hoxie, J. A., WigDAHL, B., and Gonzales-Scarano, F. (1989). CD4-independent infection of human neural cells by human immunodeficiency virus type 1. J. Virol. 63, 2527-2533.

Hibi, M., Murakami, M., Saito, M., Hirano, T., Taga, T., and Kishiмото, T. (1990). Molecular cloning and expression of an IL-6 signal transducer, gp130. Cell 63, 1149-1157.

Horak, I. D., Povic, M., Horak, E. M., Lucas, P. J., Gress, R. E., June, C. H., and BOLEN, B. (1990). No T cell tyrosine protein kinase signalling or calcium mobilization after CD4 association with HIV-1 or HIV-1 gp120. Nature 348, 557-560.

Jordan, C. A., Watkins, B. A., Kufta, C., and Dubois-Dalque, M. (1991). Infection of brain microglial cells by human immunodeficiency virus type 1 is CD4 dependent. J. Virol. 65, 736-742.

KAISER, P. K., OffermanN, J. T., and LiPTON, S. A. (1990). Neuronal injury due to HIV-1 envelope protein is blocked by anti-gp 120 antibodies. Neurology 40, 1757-1761.

KETZLER, S., WeIS, S., HAUG, H., and BUDKA, H. (1990). Loss of neurons in the frontal cortex in AIDS brains. Acta Neuropathol. 80, 92-94.

Kornberg, L. J., Earp, H. S., TURner, C. E., Prockop, C., and Juliano, R. L. (1991). Signal transduction by integrins: Increased protein tyrosine phosphorylation caused by clustering of $\beta_{1}$ integrins. Proc. Natl. Acad. Sci. USA 88, 8392-8396.

Kozlowski, M. R., SANDleR, P., LIU, P.-F., and Watson, A. (1991). Brain-derived cells contain a specific binding site for gp 120 which is not the CD4 antigen. Brain Res. 553, 300-304.

KUHLMANN-Krieg, S., SOMmer, I., and Schachner, M. (1988). Ultrastructural features of cultured oligodendrocytes expressing stagespecific cell surface antigens. Dev. Brain Res. 39, 269-280.

KYHSE-ANDERSEN, J. (1984). Electroblotting of multiple gels: a simple apparatus without buffer tank for rapid transfer of proteins from polyacrylamide to nitrocellulose. J. Biochem. Biophys. Methods 10, 203-209.

Lasky, L. A., Nakamura, G., Smith, D. G., Fennie, C., Shimasaki, C., Patzer, E., Berman, P., Gregory, T., and Capon, D. J. (1987). Delieation of a region of the human immunodeficiency virus type 1 gp120 glycoprotein critical for interaction with the CD4 receptor. Cell 50, 975-985.

LI, X. L., MOUdGIL, T., VINTERS, H. V., and Ho, D. D. (1990). CD4-independent, productive infection of a neuronal cell line by human immunodeficiency virus type 1. J. Virol. 64, 1383-1387.

LIPTON, S. A., SUCheR, N. J., KAISER, P. K., and DREYER, E. B. (1991).
Synergistic effects of HIV coat protein and NMDA receptor-mediated neurotoxicity. Neuron 7, 111-118

LIU, Z.-Q., WOOD, C., LeVY, J. A., and CHENG-MAYER, C. (1990). The viral envelope gene is involved in macrophage tropism of a human immunodeficiency virus type 1 strain isolated from brain tissue. $J$. Virol. 64, 6148-6153.

Maddon, P. J., Dalgleish, A. G., McDougal, J. S., Clapham, P. R., WEISS, R. A., and AXEL, R. (1986). The T4 gene encodes the AIDS virus receptor and is expressed in the immune system and the brain. Cell 47, 333-348.

MCARTHUR, J. C. (1987). Neurologic manifestations of AIDS. Medicine 66, 407-437.

McConkey, D. J., OrRenius, S., and Jondal, M. (1990). Cellular signalling in programmed cell death (apoptosis). Immunol. Today 11, 120-121.

MerRILL, J. E., and ChEN, I. S. Y. (1991). HIV-1, macrophages, glial cells, and cytokines in AIDS nervous system disease. FASEB 5 , 2391-2397.

Mizrachi, Y., Zeira, M., Shahabuddin, M., Li, G., Sinangil, F., and VOLSKY, D. J. (1991). Efficient binding, fusion and entry of HIV-1 into CD4-negative neural cells: A mechanism for neuropathogenesis in AIDS. Bull. Inst. Pasteur 89, 81-96.

Ou, C.-Y., KWOK, S., MitChell, S. W., MACK, D. H., SMinsky, J. J., Krebs, J. W., Feorino, P., Warfield, D., and Schochetman, G. (1988). DNA amplification for direct detection of HIV-1 in DNA of peripheral blood mononuclear cells. Science 239, 295-297.

Price, R. W., Brew, B., Sidtis, J., Rosenblum, M., SCheck, A. C., and ClEARY, P. (1988). The brain in AIDS: Central nervous system HIV1 infection and AIDS dementia complex. Science 239, 586-592.

Pulliam, L., Herndler, B. G., Tang, N. M., and McGrath, M. S (1991). Human immunodeficiency virus-infected macrophages produce soluble factors that cause histological and neurochemical alterations in cultured human brains. J. Clin. Invest. 87, 503512

Ranscht, B., Clapshaw, P. A., Price, J., Noble, M., and Seifert, W (1982). Development of oligodendrocytes and Schwann cells studied with a monoclonal antibody against galactocerebroside. Proc. Natl. Acad. Sci. USA 79, 2709-2713.

Schmitt, D., Dezutter-Dambuyant, C., hanau, D., Kolbe, H. V. Kieny, M. P., Cazenave, J. P., and Thivolet, J. (1990). In vitro binding and internalization of HIV envelope glycoproteins by human epidermal Langerhans cells does not require the CD4-gp120-bind ing site. Res. Virol. 141, 209-215.

Soppet, D., Escandon, E., Maragos, J., Middlemas, D. S., Reid, S. W., Blair, J., Burton, L. E., Stanton, B. R., Kaplan, D. R. Hunter, T., NikOlics, K., and PARADA, L. F. (1991). The neurotrophic factors brain-derived neurotrophic factor and neurotrophin-3 are ligands for the trkB tyrosine kinase receptor. Cel/ 65, 895-903.

Souinto, S. P. Stitt, T. N., Aldrich, T. H., Davis, S., Bianco, S. M. RadziejeWSKI, C., Glass, D. J., Masiakowski, P., Furth, M. E., Valenzuela, D. M., Distephano, P. S., and Yancopoulos, G. D. (1991). trkB encodes a functional receptor for brain-derived neurotrophic factor and neurotrophin-3 but not nerve growth factor. Cell 65, 885-893.

Wahl, S. M., Allen, J. B., McCartney-Francis, N., Morganti-Kossmann, M. C., Kossmann, T., Ellingsworth, L., Mal, U. E. H., MerGENHAGEN, S. E., and ORENSTEIN, J. M. (1991). Macrophage- and astrocyte-derived transforming growth factor $\beta$ as a mediator of central nervous system disease. J. Exp. Med. 173, 981-991. 